\title{
Agrarian Change and the Initial Development of an Aboriginal Bourgeoisie in Australia
}

\author{
A.J. SMITH AND SCOTT MACWILLIAM
}

\begin{abstract}
While the commercial ambitions of indigenous capitalists are continuously displayed in Australia, little is known about the origins and initial development of the class. In this essay one area of the country, the north-west of Western Australia (WA), is chosen to show how changes in the principal agricultural industry opened space for Aboriginal commerce. Despite the opposition of State governments and existing firms that dominated cattle and sheep production, this space was enlarged as pastoralism underwent major changes. The rise of the indigenous bourgeoisie was also facilitated by the growing power of the class's political representatives in electoral and in executive politics. Parallel with changes in Australian federalism, which gave the national government increased financial and other powers, Aboriginal representatives captured this shift for commercial advantage.
\end{abstract}

Keywords: pastoralism, Aboriginal commerce, indigenous capitalists, hybridity, political power

\section{INTRODUCTION}

Despite the growing prominence in Australian commercial and political life of an Aboriginal capitalist class, the origins and advance of this bourgeoisie to such a position remains little understood. While a subsequent essay will examine the later advance of the class into mining and other areas, as well as show the extent of its national ambitions, here the rural regional origins of the class are examined. These beginnings were most apparent in specific parts of the country, with the north-west of Western Australia prominent. That this is where the subsequent moves into mining are pronounced makes the region particularly significant for tracing the origins of the class. As is shown here, international and national changes in commodity production and state power were also important for the class's advance, as some of the focus remained upon pastoral and related arenas of accumulation in the North-West.

Particular emphasis is placed upon how the class began and overcame earlier barriers to its growth. These barriers arose out of the predominance since the 1890s of other capitalist enterprises and owner-occupiers who operated cattle and sheep stations in the North-West. These enterprises, which supplied meat and wool for international and domestic markets, were dependent upon political and state power to check the aspirations of indigenes who tried to enter pastoral and other commercial areas. The reliance upon resident indigenes for the operation of stations which were initially labour-extensive also resulted in the birth of 'mixed race' descendants. Some of these descendants remained at stations occupying intermediate positions in the operation of the enterprises. As is shown here, hybridity provided an

A.J. Smith is an independent scholar. E-mail: antonyjonathonsmith@gmail.com. Scott MacWilliam, Visiting Fellow, State, Society and Governance in Melanesia Program, Australian National University, Canberra, ACT 0200, Australia. E-mail: u4031629@uds.anu.edu.au

The authors wish to thank the anonymous reviewers for their comments and suggestions. 


\section{A.J. Smith and Scott MacWilliam}

important means by which some indigenes subsequently became the owners and operators of stations and other enterprises (cf. Young 1995).

The essay has three sections, each of which outlines key moments in the establishment of an indigenous bourgeoisie in an important region of Australia and are briefly summarized here. The first was a phase of limited advance for indigenous capital, which lasted until the 1960s. Initially, Aboriginal labour was critical for the establishment of pastoralism in the North-West, providing unskilled and semi-skilled labour for enterprises that reared cattle and sheep on stations that covered vast areas of land. Meat and wool was exported from this region to local and international markets. The owners and operators of the stations were international firms and local European pastoralists conducting owner-occupier, family enterprises. Whatever ambitions indigenes had to become the owners of stations and associated commercial activities were repeatedly blocked through the class and state power exercised by the predominant pastoral enterprises. Indigenes were forced to remain in the region as a labour force and forced to restrain any substantial ambitions to be bourgeois during this first phase. Only a few enterprises owned by indigenes were established and survived initially.

The second phase of the indigenous bourgeoisie's advance occurred as earlier nonindigenous enterprises, capitalist firms and owner-occupiers vacated stations and commerce in the region. During the late 1960s and early 1970s, major changes occurred that accelerated the pace of indigenous accumulation. An initial post-war period of substantial price increases for produce was followed by a rapid decline and a profitability crisis for many pastoral operations. Labour militancy and an industrial award that substantially increased wages for indigenous rural workers forced station owners to industrialize operations and reduce employment. Unemployment and impoverishment of indigenous populations occurred as the responsibility for their welfare became a greater national, Federal government responsibility. Formally educated and politically active Aborigines, supported by other politicians and public servants, pushed for major reforms to the provision of services, including finance to support indigenous commercial activities. A major takeover of many pastoral properties and commercial activities in proximate country towns began just as wages fell, unemployment rose and State resources were channelled into rural areas to ameliorate hardship.

During the third phase of indigenous capital's development, over the next 30 years until the present, Aboriginal enterprises have solidified their hold over more and more pastoral properties, as well as conducting major commercial operations in the region's small towns. National and State governments, anxious to retain indigenous populations in the region for employment and welfare reasons, have supported this advance. With Aboriginal commercial and political leaders willingly accepting a trusteeship role for these populations, indigenous labour has become more and more important for indigenous capital's accumulation. An important 1992 decision by the High Court of Australia, in response to an indigenous challenge to the basis of previous land law, made possible successful claims for native title ownership of large areas of land, including in the North-West. While this form of legal title became even more important in negotiations over mining and related leases, it also facilitated the continuing rural and proximate urban expansion of indigenous capital's third phase.

\section{STUNTED BEGINNINGS}

Before colonial conquest over the peoples and territory now known as Australia, Aboriginal social relations were not static or egalitarian but dynamic and conflict-ridden, as well as hierarchical. These relations also involved individual ownership of property, including land. This pre-colonial existence was acknowledged in 1992 when the Australian High Court 
delivered a seminal verdict, known as the Mabo decision, which confirmed that prior to European colonization Aboriginal society had developed sophisticated notions of land tenure and ownership. The decision overturned the previous legal fiction of terra nullius, which determined that there was no concept of ownership in pre-European Aboriginal society. Within pre-European Aboriginal society, there were also wide-scale trading relationships.

However, the advent of colonization and capitalist commerce destroyed the existing social structure. In many regions of Australia, especially pastoral locations (such as those in the North-West), the advance of the European commercial frontier effectively ended the prior terms of Aboriginal occupation and the possibility for further colonizing of land by indigenous populations. L.R. Hiatt argues that 'Just as pastoralists now depended on their properties to provide grass for their cattle and sheep, so Aborigines had previously depended on these same areas to nourish their kangaroos ... [b] efore the appropriation of their territories' (1996, 18). The convenient view held by the colonial administrations that there was no concept of landownership (terra nullius) among the indigenous population before European settlement justified the appropriation of Aboriginal land for the establishment of pastoral operations.

Pastoralism transformed indigenous existence in the region, primarily through proletarianization of populations that had previously travelled widely over the countryside as hunters and gatherers, and engaged in trading. The change also meant the elimination of spaces available for these previous activities. In north-west WA, the late nineteenth and early twentieth centuries were moments when the commercial frontier expanded rapidly. There were little in the way of either British, colonial or national government checks on how the indigenous population was treated by European settlers. In the period from colonial settlement (between 1860 s and the 1880s) until the late 1960s, the dominant pastoral industry required many workers and this labour force consisted mostly of 'Aboriginal labour that was forcibly domiciled on pastoral stations, government reserves or church missions' (Smith 2002, 553).

Pastoralists who had travelled in the nineteenth century either from eastern Australia or southern Western Australia to settle on north-west agricultural large-holdings treated the indigenous population along the lines described by author and prominent member of one of the leading pastoral families, Mary Durack. Durack wrote:

All over the country young natives ... were being recruited for station work ... A black received no payment other than the basic necessities of life ... If he 'cleared out' he would be tracked down ... while any other white man employing him without the consent of his original master would be breaking an unwritten law. (Durack 1959, 305)

As a consequence of the pastoral industry and its requirement for large amounts of labour (and the government policies designed to contain populations in regional areas), substantial Aboriginal populations remained and still reside in the north-west of Australia. However, as our study shows, it was not only indigenous labour, a working class that was formed at this commercial frontier, but also the initial elements of an indigenous bourgeoisie. Meanwhile, European settler land appropriation as well as the trading and other enterprises associated with pastoralism also stalled any possibility of wide-scale indigenous commercial operations. Further, as is shown below, attempts by ambitious indigenes to became pastoralists and successful commercial figures were blocked by State officials determined to preserve the dominance of European-owned and controlled enterprises.

In Australia, the pastoral industry involves the grazing of large herds of beef cattle and sheep for wool on vast land holdings. In Western Australia, the pastoral industry was, for most of the first half of the twentieth century, an extremely important sector of an economy that 


\section{A.J. Smith and Scott MacWilliam}

was principally based on primary production. Pastoralism's dominance continued into the 1960s. In 1964-5, pastoral production (37.9\%) was the single largest component of primary production in the State, followed by grain-growing agriculture (34.8\%). Between 1965 and 1968 pastoralism, which averaged 31.8 per cent of all output, was the second-largest contributor to the WA economy after cropping agriculture (average 39.6\%). ${ }^{1}$ Between 1951 and 1969, the Kimberley region of the North-West was the single largest regional producer of beef in Australia. (Australian Bureau of Statistics 1971, 338)

The necessary separation of labour from the primary means of production (i.e. land) as pastoral and other European enterprises became dominant presented first the colonial, then after 1901 when Australia became a federal nation-state, the WA State government administrations with the question of how to make that section of the now landless population both productive and orderly. As former Governor General, Territories Minister and historian Paul Hasluck noted:

From various causes, the white man came to recognise that ... [there was] placed on him a grave responsibility. During the first quarter of the ... [twentieth century] men became familiar with the idea of guardianship of native races in colonization. Phrases such as 'trusteeship', 'dual mandate', 'sacred trust of civilization' and even 'white man's burden' passed current. $(1942,11)$

The project of state trusteeship, devised on the basis of the experience of industrial development in Europe and colonial rule in Africa, enlisted the institutions of state, church and pastoral management. In many regions of northern Australia (including the North-West), state trusteeship determined that the now relative surplus populations of indigenes would largely be confined to mission settlements, reservations or pastoral leases. These arrangements perfectly suited the labour requirements of expanding European settler enterprises, including in the predominantly pastoral regions of the North-West, where the prevailing relations of production were labour extensive. As Hasluck noted, the 'difference between northern and southern conditions was that the natives had a greater economic importance in the north ... [In] the pastoral industry the natives were essential to white enterprises' (Hasluck 1942, 31).

During the late nineteenth to the early twentieth century period, against the efforts of colonial and State administrations, as well as the European settlers, a handful of Aboriginal enterprises also managed to eke out a commercial living. Their survival led to largely unsuccessful demands from at least the 1930s for the control and ownership of land by Aborigines (Palmer 1988, 1). In 1928, The West Australian newspaper reported that a number of local Aboriginals, some of whom had become farmers, plus the sons of white male pastoralists and Aboriginal women came together to form a short-lived political pressure group. They lobbied the State Labor government and its Premier (Philip Collier) for citizenship rights, including the right to own property. The initiatives were vehemently opposed by the agricultural and pastoral industries, which successfully exerted pressure on State governments with the result that these demands by Aboriginal activists were quickly silenced (Bolton 1981, 142).

An exemplar of the early commercial activities by indigenes was the Northern Development and Mining Company, formed in the early 1940s. This was the first Aboriginal company registered in WA, and possibly even Australia according to Don McLeod, a white political activist and one-time member of the Australian Communist Party, as well as director of the firm. McLeod was convinced that Aboriginal-controlled enterprises would lead to Aboriginal

1 See also Smith (2002), especially chapter three.

(C) 2013 John Wiley \& Sons Ltd 
'self-sufficiency' (McLeod 1984, 100). It is worth noting that McLeod's views were similar to the line advanced in the 1920s by the Comintern. On the other side of the globe, the value of indigenous entrepreneurial activity was acknowledged and supported, in the belief that a local bourgeoisie could provide an effective means to combat and eventually overcome imperial and colonial power (Cowen and MacWilliam 1996, 23-74).

Against strident opposition, the Northern Development and Mining Company became involved in mining and later pastoralism in the Pilbara region in the north-West. A WA government report noted that the company was viable and that it 'will become a permanent establishment'. The report goes on to suggest that:

To a large extent, complete success is dependent upon the success of its mining operations, the sole source of finance for all activities. At the present time the chief mineral being mined is columbite, valued up to $\AA^{3,000}$ per ton. If the demand continues the project is an assured success. (McLeod 1984, 100)

Later, during the early 1950s, the Northern Development and Mining Company commenced pastoral operations by purchasing four properties in the Pilbara region (McLeod 1984, 104). However in spite of, or more correctly because of, the successful commercial enterprises undertaken by the Northern Development and Mining Company, there were deliberate and effective acts of sabotage. As an indication of the concern shown by white business interests towards McLeod and associated enterprises, the Secretary of the Pastoralists and Graziers Association wrote to the Minister for Native Welfare and stated that:

The Yalgoo District Committee of this Association has notified the Executive of the presence of Mr D. McLeod in the Yalgoo area. The Association is deeply concerned at his presence there as it is only too mindful of his activities ... and its effects both on the native and pastoral industry ... No doubt your department is watching the activities closely. The Association wishes to assure you of its assistance should it be needed. (Secretary of the Pastoralists and Graziers Association of Western Australia 1963)

According to McLeod, between the 1940s and the early 1960s, 'the authorities were bent on wrecking any [Aboriginal] project' (McLeod 1984, 105). He concluded that ' $\mathrm{t}]$ he destruction of our companies was accomplished quite deliberately by a morally corrupt state' $(1984,122)$. Sustained government action, often utilizing draconian means on behalf of vested interests, ultimately succeeded in closing the company's operations. For example, the Yandeyarra pastoral lease was forfeited because the enterprise had not 'complied with the [officially mandated] stocking conditions'. However, as the Report of the Pastoral Leases Committee also noted, it was usually the case that the stocking conditions on these types of pastoral lease 'cannot be complied with without overstocking and degradation of the country. Conditions in pastoral areas vary so much that it is impossible to lay down rigid general provisions regarding either the maximum or minimum stocking rate' (Pastoral Leases Committee 1963, 93). ${ }^{2}$ Significantly, 'in some instances properties were purchased by Eastern States [white] interests who ... considerably over-estimated' the land's carrying capacities (Pastoral Leases Committee 1963, 93) and subsequently exceeded prescribed stocking rates without penalty. The selective leniency neatly illustrates the priority given by the State administration to the predominant non-indigenous commercial enterprises. A condition not uniformly applied to all pastoral

2 A committee appointed to inquire into and report matters relating to the Pastoral Industry of Western Australia. 


\section{A.J. Smith and Scott MacWilliam}

activities in the region, a penalty for overstocking cattle or sheep on a pastoral lease, was invoked as a means of stripping the company of the lease (McLeod 1984, 101).

In the mid-1950s, the remaining assets of the Northern Mining and Development Company, including the mining and pastoral operations, were broken up and sold to corporations such as Bell Brothers - a large non-indigenous Western Australian company (McLeod $1984,104)$. However two decades later, when indigenous enterprises began a major move into the ownership and operation of cattle and sheep stations, Northern Mining's pastoral operations could be seen as a harbinger of a major change that was to come, initially in pastoralism and even later in mining.

After the demise of the Northern Mining and Development Company, McLeod was approached by some of the former members of the company to assist in building a new company. In 1955, the Pindan Company was established and by 1959 employed 300 Aboriginal workers, approximately one third of the population in the area of its operation: 'There were six work camps, an administrative camp and two others, mining for eight different minerals including tin, copper, wolfram, gold and manganese ... They also had a joint venture with Albert G Sims Limited, a metal purchasing company' (Holcombe 2006, 6). Sims was an Eastern States company - now Sims Metal Management, a global company. Albert Sims, the company's founder, was a member of the Australian Socialist Party. By the 1950s, with the founder's son now managing the firm, it was competing against major international and domestic capitals, including Broken Hill Pty Ltd (see below), over the right to export scrap metal. ${ }^{3}$ Not being as beholden to local political or business directives, Albert G Sims Ltd could trade with an Aboriginal enterprise, whereas local metal merchants would risk political and other sanctions.

Seven indigenous shareholders, including a woman, together with McLeod owned the Pindan Company. In the company's rules, it was stated that 'no other European could become legal members of the Company ... Three of the seven Aboriginal shareholders regarded as the three most senior men were known as Directors - being Ernie Mitchell, Peter Coppin, and Coombi'. Today's indigenous business leaders often invoke traditional seniority in Aboriginal 'culture' to support their commercial aspirations, especially in regional areas as has been noted by Holcombe $(2006,8)$.

In December 1960, the Federal government lifted a 22-year embargo on the export of iron ore (Black 1981, 461). The ban had been imposed to stop Japanese access to this resource during the build-up to the Second World War and to limit the competition in steel production for the benefit of Australian firms. In the early 1960s Mitchell, one of the Pindan directors, self-published a pamphlet calling for a government licence to allow his organization to export iron ore from Mt Goldsworthy (a rich and massive source of iron ore) in the Pilbara region. According to Mitchell:

The granting of an export licence to us, the only successful self-contained Aboriginal group in Australia, would go a long way towards silencing the many critics of Australia's policy towards the original Australians ... We do not ask for an export licence on terms different from those that would be applied to other persons ... We can make arrangements equivalent to those of any other sound business concern, and we have a pool of labour, resident in the district, and accustomed to working in the climactic and other arduous conditions of the Mt Goldsworthy area. (Mitchell undated)

3 We are indebted to one of the journal's anonymous reviewers for some of the information on Albert G Sims Ltd and its founder utilized here. 
Despite the pleas of the Pindan officials, in 1962 a subsidiary company of the major Eastern Australian mining and steel manufacturing firm Broken Hill Proprietary Limited (BHP) was granted a lease to mine ore at Mt Goldsworthy (Crowley and de Garis 1970, 98). The lease to Mt Goldsworthy Ltd is significant too because of what it shows about early 1960s political and state power in Australia. For BHP, a national company with access to political power at the Federal and State level was granted the licence to mine ore at the expense of both Western Australian white and black capital. Lang Hancock, a local mining rentier and would-be industrialist, was also denied the right to export ore from various locations throughout the Pilbara. Unlike Pindan, however, Hancock subsequently received substantial mining royalties from leasing the land on which a partner and he had discovered iron ore. Primarily through inheritance of these leases from her father, Hancock's daughter Gina Rhinehart is reportedly the richest woman in the world (Smith and MacWilliam forthcoming b).

It was not until the 1970s and 1980s, with the advent of localized land rights legislation and land transfers, that Aboriginal corporations - this time represented by well-organized political structures - would enter into partnerships and other arrangements with mining companies to receive royalty payments as well as associated economic benefits from internationally significant commercial operations conducted on 'their land'. As a consequence of State and Commonwealth support for BHP and rejection of Pindan's request, there became a distinct contrast between the scale of Aboriginal business activities during the first and subsequent phases. The essay now turns to the second phase of the indigenous bourgeoisie's advance.

\section{AGRARIAN CRISIS, CHANGES IN STATE AND CLASS POWER}

\section{Prices, Profitability and Pastoral Production}

From the late 1960s, major reductions in the demand for and the prices of many agricultural commodities, including beef, affected the operation and ownership of stations in the region. By the mid-1970s, beef had reached its lowest price in over two decades, and a severe slump forced changes in Australia's beef industry. Where production was largely geared to export, as in the north-west of WA to the US hamburger meat market, the effect of the international downturn was especially substantial. Between 1973 and 1975, the number of cattle exported from Kimberley properties fell from over 100,000 to less than half that number. Even a partial recovery by 1978 to about 80,000 head of exported cattle signalled that a major transformation was occurring. The terms of the change included that the region was becoming relatively less important for cattle production in the State, a trend that continued into the twenty-first century even as total cattle numbers increased again (Smith 2002, 124-8; Meat and Livestock Australia Limited 2012).

One effect of the downturn in the global beef market was the quickening pace at which the concentration of pastoral ownership occurred, due to the difficulties being encountered by the smaller owner-operator businesses. The Kimberley Pastoral Industry Inquiry, set up in 1983 with a final report published 2 years later, recognized that a major transformation of the industry was happening, which included the accelerating concentration of the ownership of pastoral leases and businesses into the hands of what it termed 'absentee owners'. As well as the concentrations in ownership, there were increases of capitalization and greater use of mechanization for stock management. The initial report of the Inquiry also pointed to the expanding ownership of pastoral enterprises by Aboriginal 'owner operators' (Jennings 1984, 


\section{A.J. Smith and Scott MacWilliam}

213). This change was made possible because when previous station owners or occupiers sold or relinquished 'their leases often the local Aboriginal group prevail[ed] upon government to purchase the station' (Sullivan 1996, 17). In 1983, Aboriginal-controlled enterprises owned and operated 11 pastoral leases and were classified by the Inquiry as 'owner operators in their own right' (Sullivan 1996, 34).

In the name of protecting their 'communities, welfare and culture', Aboriginal businesses actively pursued the acquisition of pastoral land. 'Protection' of the indigenous population had become increasingly necessary in the region, partly as an effect of changes in the pastoral industry upon Aboriginal workers. As the WA Commissioner of Native Welfare indicated in the 1972 Annual Report:

The Aboriginal work force was probably the first and most seriously affected by the general economic recession. With approximately $40 \%$ of the total Aboriginal workforce directly involved in agricultural, pastoral and related activities ... it is this sector which is most affected by reduced wool prices, drought and changed operating techniques ... (17; also cited in Smith 2002, 124)

In 1968, as the boom approached its end, compulsory award wages were introduced into an industry where previously Aboriginal workers had been paid at lower rates than white employees. Partly as a consequence of the increase in wages, many Aboriginal workers and their families who had previously lived on Kimberley cattle stations were expelled. Between 1969 and 1972, there was a reduction of 43 per cent in the numbers of Aborigines in agricultural, primarily pastoral employment. One consequence of the decline was a major drift of indigenous unemployed to small and middle-sized urban centres in the region and further afield in WA. The populations of Halls Creek, Wyndham and Derby 'almost doubled overnight', while a smaller settlement at Turkey Creek 'was suddenly transformed into a refugee camp of more than 300 people' (Yu 1994, 25). By 1975, the population of Fitzroy Crossing, another town in the region, had increased to over 2,000 people (Yu 1994, 26).

The remaining wage jobs in the pastoral industry for Aborigines often required males to reside on stations for at least part of the employment period, with women and children moving into urban settlements. In these centres, generalized impoverishment was characterized particularly by shortages of accommodation, alcoholism and crime. Between 1965 and 1969, with over 30 per cent of the indigenous population in WA living in the Kimberley region, there was a near doubling in the number of criminal offences by Aboriginals (Smith 2002, table 4.3, 134).

\section{Changes in Commonwealth - State Government Relations and Indigenous Political Representation}

At the same time as the north-west region and the pastoral industry in it underwent the structural transformations just outlined, several important shifts occurred in state and political power in Australia. These enlarged the potential for indigenous capital in the region, in pastoralism and commerce initially, but subsequently also in mining. As a consequence of the successful 1967 referendum, which amended the Australian constitution, the national government's responsibility for the welfare of indigenous people was extended from its previous confinement to the Northern and Australian Capital territories to include all indigenous people regardless of their location. From then on, Commonwealth and State governments each had various forms of authority over indigenes, which were exercised through distinct departments and agencies. Thus where the growing unemployment and under-employment was especially pronounced among indigenous populations, as in the north-west of WA, the 
newly responsible Federal government and State governments were both confronted with the prospect of significant and potentially long-term social problems should the drift to rural towns and then cities not be arrested.

Since at least the middle to late 1950s, at the same time as indigenous capital continued to face important barriers, politically active Aborigines from intermediate strata and would-be bourgeois were joined by white activists to press for major political reforms. Increased educational opportunities and expanded State employment enlarged the space in which the reformers could push for changes, including in the political representation of indigenes. ${ }^{4}$

By the late 1960s to early 1970s, it was becoming more and more obvious that existing policy for dealing with indigenes, encapsulated by the expression 'state trusteeship', was incapable of dealing with these changed circumstances. To maintain social order and revitalize accumulation in the region, a new, alternative policy regime had to both halt the drift of labour from the countryside and reabsorb already displaced and now unemployed Aboriginals. The task had to be undertaken in an economic environment with no obvious industries to attach to such a policy. The evolving policy regime saw Aboriginal leaders increasingly being given the responsibility to ameliorate the declining conditions of those suffering poverty, unemployment and social dislocation. A substantial aspect of the new policy determined that the small number of Aboriginal people already involved in commercial operations, as well as a politically active leadership, would be required to act as trustees for the welfare of Aboriginal people. In the process, the new policy of indigenous trusteeship provided an Aboriginal class of capital - which hitherto had been actively restrained by the state - access to finance, labour and land. The requirements for finding new ways to re-engage indigenes in regional labour markets also saw many earlier checks on indigenous business formation fall away.

One policy change with continued importance for both employment and indigenous accumulation was the 1976-7 introduction of the Community Development Employment Projects (CDEP) scheme by the Liberal - National Country Party Coalition Government led by Prime Minister Malcolm Fraser. Aboriginal and other enterprises were greatly assisted by CDEP that significantly reduced their labour costs. As CDEP organizations, Aboriginal pastoral stations employed participants who relinquished their 'unemployment benefits or training allowances' and were in return paid subsidized wages to work for their CDEP organizations. The continued importance of the subsidy in the North-West can be gauged from 1998 figures, which indicated that $\$ 235$ million - or ' 63 per cent of the CDEP scheme's funds' was utilized as an 'offset against participant's unemployment benefits that would otherwise be payable through the Department of Social Security' (ATSIC 1998, 43) in the Kimberley.

This moment of restructuring in state administration is important historically even if so far there have been mixed results in terms of transforming surplus labour into workers producing surplus value. However, the changes did release the pent-up entrepreneurial commercial aspirations of some indigenes. Indigenous trusteeship facilitated the further advance of Aboriginal businesses in the pastoral industry and related enterprises in the north-west of WA.

From the early 1970s, the attempt to both ensure spatial immobility of relative surplus populations and reattach that labour to the available other means of production, particularly land, required 'reinventing' race and ethnicity, this time on behalf of an aspiring indigenous leadership. As the Western Australian Commissioner of Native Welfare pointed out in 1972:

4 For some parallels between the political economy of this period in the United States, Canada and Australia, see Smith (2002, 42-55). 


\section{A.J. Smith and Scott MacWilliam}

The emergence of Aboriginals who provide an articulate voice for their peoples' aspirations is a new phenomenon, which has characterised the last few years. Their presence on television and radio is no longer a novelty, they are very much a part of the media's daily material and their views sought and published. Once an inarticulate and ignored segment of society, they are steadily becoming a political force [our emphasis]. (Commissioner of Native Welfare 1972, 9)

A principal preoccupation of the Aboriginal leadership was to shift government policies away from programmes that had been historically 'designed and executed by white administrators and based on their judgments of the needs of the situation' (Turner 1997, 6). According to Charles Perkins, who was later to become head of the Federal Department of Aboriginal Affairs, the 'main single emphasis of the political resurgence' was the push by the Aboriginal leadership for 'Aboriginal and Islander self-management and self-determination' (Perkins 1988, 238). Successive Federal governments came to agree with the view, expressed by Perkins, that 'Aboriginal leaders best understood the cultural and social needs of their people' and as a result found themselves 'to be directly involved in decision making and program and service delivery'. These initiatives 'naturally' and purposefully 'encouraged the formation of new community and other service-based organisations' (Perkins 1988, 238). Powerful white bureaucrats also were influential in formulating the shift, advocating various measures to enhance indigenous 'self-determination' (Rowse 2002, 324-52).

Even before the 1992 High Court Mabo decision, an important element of indigenous trusteeship policy involved the transfer of considerable amounts of land to the Aboriginal commercial leadership. Both large and small properties, such as pastoral stations, were handed over to indigenous corporate bodies and individuals alike on the basis of reintegrating and making productive the growing number of unemployed people. Federal and State governments, in close cooperation with the Aboriginal leadership, financed and initiated many projects conducted through indigenous enterprises on 'Aboriginal land'. In a bid to retain people in remote and regional areas 'Land purchase ... figured prominently among the many measures designed to promote policies of self-determination and self-management' (Young 1988 , 1). The transfer of land to Aboriginal control increasingly required the employment of corporate commercial practices. It was believed that the newly constructed Aboriginal business operations could be an effective way of creating employment. This reformed relationship between indigenous people, those who laboured and those who owned and controlled enterprises, and the land marked a major watershed for Aborigines in the region.

\section{Joining Business and Politics}

Our account now turns to providing prominent instances of the combination of agrarian change, and the shift in state and political power during the second phase of indigenous capital's advance. Along the lines of the hybridity previously noted, individuals and families of 'mixed European and Aboriginal' heritage also became involved in giving effect to the new policy. In the north-west of WA, the Department of Native Welfare saw Ernie Bridge - who at the time was a successful businessman and politician - as one effective way of generating local employment and thereby a potential instrument for soaking up some of the growing unemployed. Bridge was becoming perhaps the leading representative of the emerging Aboriginal capitalist class as it expanded in the region. In a government report, Bridge was described as a 'caste native' (Commonwealth Department of Labour and National Service 1969). Bridge was 'grandson on his father's side of a pioneering overlander [and pastoral station owner] and on his mother's side of a senior man of the local Aboriginal clan in the 
Halls Creek district' (Bolton 1981, 17). Bridge inherited and then operated many businesses, including several Kimberley pastoral stations, a butcher's shop, a general store, a picture garden, the MacRobertson Miller Airline agency and a contract mustering operation, and was also for a time Halls Creek Shire President.

In 1975, after an 'ugly conflict' and 'race riot' in the Skull Creek area of Laverton - a town in the Goldfields region of WA - Bridge was appointed by the Federal and State governments to inquire into this and other conflicts. It was an experience that led Bridge to accept what he termed a Labor Party approach to politics. ${ }^{5}$ One aspect of the approach involved a philosophy that viewed individualism and enterprise through the lens of tradition. The view is encapsulated in Bridge's statement:

Throughout my efforts over the years to move governments towards restructuring the Kimberley pastoral industry I have stressed one factor above all others - the quality of the individual pastoralist [as against absentee owners]. I have referred to the owner/ operator and to family operations. It is hardly a revolutionary concept, in fact it is as old as agriculture to say that the men and women who live on their land ... remain the best guarantee of a productive rural sector. (Bridge 1985, 6)

In the 1977 Western Australian State election, Bridge was the endorsed Labor Party candidate for the seat of Kimberley. In a bitter and hard fought campaign, Bridge narrowly lost to the Liberal candidate Alan Ridge. However, in February 1980 Bridge was elected to the seat, becoming Western Australia's first Aboriginal to sit in the State parliament (Bridge 1985, 175). Bridge subsequently became Australia's first Aboriginal Cabinet Minister. He held numerous portfolios, including most notably Aboriginal Affairs, Small Business and Agriculture, Water Resources and the North-West. Prior to being elected the member for Kimberley, Bridge 'was well known ... in Aboriginal communities through his work on the Aboriginal Lands Trust and Aboriginal Land Fund Commission' (Hawke and Gallagher 1989, 92).

While Bridge's case was especially prominent, and became a yardstick for other subsequent indigenes during this second phase of indigenous accumulation, he was not alone. During the 1950s and 1960s, another leading Aboriginal businessman Peter Coppin - a former director of The Pindan Company (see above) - was involved in mining in the Pilbara region. However, as noted in his book Kangkushot, Coppin was not 'driven by the mining enterprise', but like others in the pastoral region, 'preferred instead the stock and horse work that [he] had grown up with and become so adept at' (Read and Coppin 1999, 134). In 1972, after the policy move to indigenous trusteeship, negotiations commenced between the Department of Native Welfare, the Western Australian State government and Peter Coppin's Mugarinya company. Negotiations centred on the control of the Yandyerra pastoral operation on a perpetual lease from the Aboriginal Lands Trust (Read and Coppin 1999, 134). Unlike under the previous policy regime where indigenous enterprise was purposefully blocked, with Yandyerra stripped from Aboriginal ownership, in 1974 the transfer of the lease went smoothly (Read and Coppin 1999, 153). Coppin, in undertaking control of the pastoral enterprise, stated that he 'had a broad vision for Yandyerra'. To create employment for the unemployed, he saw the need to make the station 'commercially viable through the cattle business' (Read and Coppin 1999, 154).

Other 'mixed race' or 'caste native' examples of hybridity in the Kimberley who became commercially important, particularly under the policy of indigenous trusteeship, include the Cox family. The family, who own and operate the Louisa Downs Pastoral Station are the

5 In The West Australian, 21 February 1986. 


\section{A.J. Smith and Scott MacWilliam}

direct descendants of the white pastoralist William Cox, who also purchased Koongie Park (a property later owned by the Bridge family). During the 1890s, William Cox selected Louisa Downs (Schubert 1992,1). On arriving at the future station, he recruited a large number of Aboriginal workers from the surrounding region, who came to live at the property, in an area termed the camp. Soon after establishing the station, Cox acquired a 'young native woman' as a housekeeper and de facto wife. When she became pregnant, the woman was sent back to the camp and another woman installed in the vacancy (Schubert 1992, 19). In 1944, when William Cox died and the estate sold, the hybrid Cox family remained on Louisa Downs.

When the opportunity provided by the Federal Labor government (1983-96) as part of its effort to return people to their 'traditional land' arose (see below), the Cox family's determination not to abandon the station made possible their successful claim to Louisa Downs. This event occurred 100 years after William Cox first arrived on the large-holding. Norman Cox, great-grandson of William Cox, now operates the station (Schubert 1992, 163). As reported:

Western Australian Aborigines took back legal title to more than half a million hectares of Kimberley land at a special ceremony at Fitzroy Crossing on 18 February 1989. The [Federal] Minister for Aboriginal Affairs, Gerry Hand, handed over title to three stations . . Norman Cox accepted title to Louisa Downs (199,000 hectares). ${ }^{6}$

The international downturn in commodity prices, the declining profitability of many pastoral stations, plus major changes in state and political power paved the way for a change of fortunes for indigenous capital. However, the real significance of these tentative advances became more important in the third phase, when indigenous commerce not only extended its reach in pastoral activities but also occupied important spaces in other forms of commerce. These included becoming the providers of consumption goods and services for indigenes and others who lived in the rapidly growing urban centres, partly the effect of the movement of indigenes off stations during the late 1960s and 1970s downturn.

\section{PASTORALISM AND TRADING OPPORTUNITIES EXPAND}

Even as cattle and sheep production expanded again over the next three decades, with beef, veal and live cattle exports increasing in amounts, the north-west of WA remained a significant contributor to the national total. While attention shifted more and more to the substantial increases in exports of minerals and natural gas, which also created room for indigenous capital's growth, pastoral activities retained some of their earlier significance. The control of increasing amounts of pastoral land and labour provided further opportunities to consolidate and expand other indigenous commercial activities in the Kimberley and Pilbara regions. The changes in the operation of stations opened commercial opportunities, as did the growth of small and middle sized urban centres. Where previously station owners had often supplied food, clothing and other goods to resident Aboriginal workers and their families, these transactions were further commercialized through shops and other enterprises in settlements and towns. State welfare funds provided for the employed and unemployed opened space for commercial activities in the expanding urban centres.

The opportunities presented for Aboriginal enterprises in pastoral and related activities were considerable. Some idea of the growth can be understood through two forms of data, one aggregate and the other by reference to an especially prominent indigenous firm, the

6 In Aboriginal Development News, winter 1986.

(C) 2013 John Wiley \& Sons Ltd 
Marra Worra Worra resource agency, and its close partner Leedal Pty Ltd. These enterprises controlled and continue to control a number of significant businesses in the north-west region.

By 1996, Aboriginal 'owner operators' controlled 22 of the 98 Kimberley pastoral leases. Five years later, the Kimberley Development Commission found that Aboriginal interests now owned 'thirty two pastoral stations' - that is, nearly two and a half times the number held in 1983 -'covering 68,000 square kilometres' (over 30\% of pastoral lands) and 'involving a cattle herd of some 75,000 head' (Kimberley Development Commission 2001, 28). The rebuilding of the pastoral industry after the earlier slump had a substantial indigenous presence beyond its earlier dominance by Aboriginal workers.

In 1979, two Aboriginal former Department of Community welfare workers established the Marra Worra Worra resource agency, which has been cited as a 'shining example of how black management can work' in the Kimberley. ${ }^{7}$ It was recognized by the founding directors of Marra Worra Worra that there was an obvious commercial potential in the welfare requirements of the Aboriginal people flooding into Fitzroy Crossing, one of the towns cited above as expanding rapidly due to the emigration of now unemployed station workers and their families. In the early 1980s, the management of Marra Worra Worra began cashing Social Security cheques for indigenous welfare recipients and at the same time arranged a 'community contribution scheme' of which a proportion of welfare payments were held over for community projects. By 1985, the turnover involved in the community contribution scheme operation alone was estimated to be $\$ 1.5$ million per annum (Sullivan 1996, 85). The commercial activities of Marra Worra Worra were organized and managed in two sections, one covering accounting and the other a so-called resource service. The activities conducted under the two sections overlapped considerably. Specifically, Marra Worra Worra's role in accounting and resource work involved 'administering social security payments [CDEP wages] ... extracting community deductions such as rent and power, or "chuck in" [individual contributions to collective debt] paying community and personal bills' (Arthur 1994, 92).

Marra Worra Worra also administered all the 'Incorporated Community accounts, made purchases and arranged other business transactions for Incorporated Communities, groups and individuals' (Arthur 1994, 92). It maintained all the accounts involving government funding, including from the Western Australian Department of Aboriginal Affairs, and the Government Auditor. It managed Aboriginal pastoral station accounts, accounts for Aboriginal contracts and paid all Aboriginal wages (CDEP) in Incorporated Communities. During 1984-5, 'some $\$ 5$ million passed through the organization' (Arthur 1994, 92).

Initially, about 30-40 per cent of Marra Worra Worra's income was derived from accounting fees (Sullivan 1996, 85). Subsequently, the pastoral enterprises managed and controlled by Marra Worra Worra generated considerable income. According to the Western Australian Department of Land Administration Lessee Contacts Report, the Bunuba Aboriginal Corporation, a close affiliate of Marra Worra Worra, controlled the pastoral stations at Fairfield, Leopold Downs and Millie Windie (Western Australian Department of Land Administration 1999). Pastoral income was also supplemented through deals with local, national and multinational mining companies over exploration on Aboriginal pastoral leases (Department of Land Administration 1999).

In 1987, Marra Worra Worra and five local 'community groups' began to operate several regional businesses through their investment company, Leedal Pty Ltd. 'The first big acquisition was a controlling interest in the Crossing Inn', known colloquially as the 'local pub',

\footnotetext{
7 In The Australian, 6-7 May 1995.
} 


\section{A.J. Smith and Scott MacWilliam}

situated in the Kimberley town of Fitzroy Crossing. In 1992-3, the Crossing Inn alcohol sales alone were estimated to be at least $\$ 3$ million. In the same year, retail sales enjoyed by the Tanunda supermarket, also in Fitzroy Crossing, were estimated in the vicinity of $\$ 2.2$ million (Crough and Christophersen 1993, 60). By 1995, in addition to ownership of the supermarket and hotel, Leedal (in partnership with the Perth-based financier Brian Coppin) had a 'one third interest in an architect's firm which does much of the government contract work in the region'. ${ }^{8}$ Leedal also owned the local caravan park. In 1995, Patrick Green, landowner and Aboriginal company director - of among others, Leedal, Marra Worra Worra resource agency and several pastoral properties - was quoted as saying: 'The bottom line . . . is you do business in Fitzroy Crossing with Leedal or you don't do business at all'. ${ }^{9}$ The practices adopted earlier by European firms to marginalize indigenous commercial efforts were now being replicated by an indigenous firm, but probably in a more inclusive manner without reference to race or ethnicity. Monopoly, as Dick Bryan noted, is a form that competition takes among capitalist enterprises (1985).

\section{CONCLUSION}

During the 1970s and 1980s, Aboriginal leaders were increasingly involved in formulating and applying the policy of indigenous trusteeship. This policy was in substantial measure an attempt to ameliorate the worsening social conditions for Aboriginal people in remote locations such as the North-West. In the process, the new policy provided an Aboriginal business class, which hitherto had been actively stymied, access to finance, land and labour. While initially the importance of Aboriginal-run enterprises was seen more in their employment potential, government support made possible the expansion of Aboriginal commercial activities. The advance occurred through pastoralism and later in other sectors of the economy. The connection between the changed terms of official support and commercial expansion was neatly expressed in a government publication that asserted that Aboriginal enterprise 'means business! Commercial, viable profitable business' (Anon).

The paper has shown that the opening of economic space and the subsequent commercial opportunities that became available have seen major increases in the scale and scope of indigenous businesses. In Australia, there has been a general lack of analysis and understanding of the emergence and advance of indigenous capital, which the paper has gone some way to illuminate. Rather, the emphasis has been much more on social conditions, welfare measures and the issue of poverty itself. As understandable as is the concern about chronic abuse of children, poor educational outcomes, unemployment, disorder and relatively short life spans among rural indigenous populations in particular, attention also needs to be directed at whether the proposed remedies are more likely to attain what earlier forms of capitalist firms and companies could not avoid - their susceptibility to international market conditions. As shown in the first section of this paper, if the demand for meat and wool initially favoured the establishment of pastoral stations and the employment of many Aborigines under particular conditions, the same properties were forced to substantially reduce their labour forces when international conditions changed.

Subsequently, a highly favoured remedy for unemployment and disorder became to attach the future of indigenous labour to the continued advance of indigenous businesses that owned 
and operated pastoral properties. Our study has tried to show some details of the history of the movement of indigenous businesses from the margins of pastoral industry in the region to a prominent position. Description of this change, which has previously been largely ignored, also raises an important question. It becomes necessary to ask what, if anything, shelters these indigenous operations from the general condition of capitalist enterprises. If the anarchy of competition and the incessant drive to accumulate holds for Aboriginal businesses too, then why would these particular companies and firms provide any greater certainty that unemployment and impoverishment can be removed than previously existed when other capitalist firms, international and local, and owner-occupiers operated pastoral stations? If this uncertainty holds for pastoral enterprises, even as state trusteeship has been replaced by indigenous trusteeship to confront a major downturn, why should an Aboriginal advance into other areas of commerce, including mining, oil and gas, and tourism, secure what an earlier phase of trusteeship could not? If improved living standards and social order cannot be assured for indigenous populations when Aboriginal bourgeois also hold or at least have a major say in shaping state power, then support for any such commercial advance should at least be questioned. Our next two essays continue this questioning (Smith and MacWilliam forthcoming $a, b)$.

\section{REFERENCES}

Anon., circa early 1990s. 'Investing in Our Future'. Aboriginal and Torres Strait Islander Commercial Development Corporation pamphlet.

Arthur, B., 1994. 'Cultural, Autonomy, Economic Equity and Self Determination Within Nation States: Australian Aborigines in Remote Regions'. Australian Aboriginal Studies, 1994 (2): 28-37.

ATSIC (Aboriginal and Torres Strait Islander Commission), 1998. Annual Report. Canberra: ATSIC.

Australian Bureau of Statistics, 1971. Western Australian Year Book, 1971. Canberra.

Black, D., 1981. 'Liberals Triumphant: The Politics of Development 1947-80'. In A New History of Western Australia, ed. C. Stannage. Nedlands, WA: University of Western Australia.

Bolton, G.C., 1981. 'Black and White after 1897'. In A New History of Western Australia, ed. C. Stannage. Nedlands, WA: University of Western Australia.

Bridge, E., 1985. 'Individuals Not Empires'. Unpublished paper delivered to Pastoral Challenge Seminar, Derby, WA (cited in the WA State Archives).

Bryan, D., 1985. 'Monopoly in Marxist Method'. Capital and Class, 26 (summer): 72-92.

Commissioner of Native Welfare, 1972. Annual Report. Perth, WA: Western Australia.

Commonwealth Department of Labour and National Service, 1969. Report on Visit to Aboriginal Communities, Missions and Pastoral Stations in the Northern Part of Port Hedland, 23 September.

Cowen, M. and S. MacWilliam, 1996. Indigenous Capital in Kenya: The 'Indian' Dimension of Debate. Institute of Development Studies, University of Helsinki. Helsinki: Interkont Books.

Crough, G. and C. Christophersen, 1993. Aboriginal People in the Economy of the Kimberley Region. North Australia Research Unit, Australian National University, Darwin.

Crowley, F.K. and B.K. de Garis, 1970. A Short History of Western Australia. Melbourne: Macmillan.

Durack, M., 1959. Kings in Grass Castles. Sydney: New Country Press.

Hasluck, P., 1942. Black Australians: A Survey of Native Policy in Western Australia, 1829-1897. Carlton, Victoria: Melbourne University Press.

Hawke, S. and M. Gallagher, 1989. Noonkanbah. Fremantle, WA: Fremantle Arts Press.

Hiatt, L.R., 1996. Arguments about Aborigines. Cambridge: Cambridge University Press.

Holcombe, S., 2006. Early Indigenous Engagement with Mining in the Pilbara: Lessons from a Historical Perspective. Working Paper No. 24/2004. Centre for Aboriginal Economic Policy Research, Australian National University, Canberra.

Jennings, B. (Chairman), 1984. Kimberley Pastoral Industry Inquiry. Department of Regional Development and the North West, 26 February.

Kimberley Development Commission, 2001. The Aboriginal Component of the Kimberley Economy, August.

McLeod, D., 1984. How the West Was Lost. Port Hedland, WA: self-published. 


\section{A.J. Smith and Scott MacWilliam}

Meat and Livestock Australia Limited, 2012. Cattle Numbers - as at June 2011. Natural Resource Management Region. North Sydney, NSW: MLA.

Mitchell, E., date unknown. 'An Opportunity for Statesmanship'. Chairman of Directors, Pindan Pty Ltd, Port Hedland.

Palmer, I., 1988. Buying Back the Land. Canberra: Aboriginal Studies Press.

Pastoral Leases Committee, 1963. Report of the Pastoral Leases Committee.

Perkins, C., 1988. 'Australian Aborigines: Politics, the Law and Aborigines'. In The Australian People: An Encyclopaedia of the Nation, Its People and their Origins, ed. J. Jupp. North Ryde, NSW: Angus and Robertson.

Read, J. and P. Coppin, 1999. Kangkushot. Canberra: Aboriginal Studies Press.

Rowse, T., 2002. Nugget Coombs: A Reforming Life. Port Melbourne, Victoria: Cambridge University Press.

Schubert, L., 1992. Kimberley Dreaming. Mandurah, WA: Wordsworth Express.

Secretary of the Pastoralists and Graziers Association of Western Australia, 1963. Letter to E.H. Lewis, Minister for Native Welfare, 29 April.

Smith, A.J., 2002. 'Development and Aboriginal Enterprise in the Kimberley Region of Western Australia'. PhD thesis, University of Western Sydney.

Smith, A.J. and S. MacWilliam, forthcoming a. 'Trusteeship Reconfigured and Rebadged'.

Smith, A.J. and S. MacWilliam, forthcoming b. 'Who Wants to be a Billionaire?'

Sullivan, P., 1996. All Free Man Now. Canberra: Australian Institute of Aboriginal and Torres Strait Islander Studies.

Turner, P., 1997. 'Public Policy in Indigenous Affairs - No Miraculous Solutions'. Australian Journal of Public Administration, 56 (2): 3-11.

Western Australian Department of Land Administration, 1999. Lessee Contacts Report.

Young, E.A., 1988. Aboriginal Cattle Stations in the East Kimberley: Communities or Enterprises. East Kimberley Working Paper No. 21. Centre for Resource and Environmental Studies, Australian National University, Canberra.

Young, R., 1995. Colonial Desire: Hybridity in Theory, Culture and Race. London: Routledge.

Yu, P., 1994. 'The Kimberley: From Welfare Colonialism to Self-Determination'. Race and Class, 35 (4): 21-33. 